TÍMÁR Balázs

tudományos segédmunkatárs

MTA TKJTI
DOI: 10.15170/DIKE.2021.05.01.17

\title{
A historiográfia új irányai
}

\section{Gondolatok Ablonczy Balázs „Az ismeretlen Trianon. Az összeomlás és a békeszerződés történetei, 1918-1921” és Hatos Pál „Rosszfiúk világforradalma. Az 1919-es Magyarországi Tanácsköztársaság története" címü kötetéről}

Horthy Miklós 1919. november 16-i Budapestre történő bevonulásakor tetemre hívta a várost, mely vörös rongyokba öltözött. E kijelentéssel - bármennyire is hangzatos, bármennyire is pátosszal teli, bármennyire is a keménykezű vezetôt igyekszik elénk idézni - több az aggály, mint a megértés. Kezdve azzal, hogy Horthy meddig maradt Szegeden, mit tett, vagy épp nem tett, miközben Budapesten tombolt a vörös hatalom, folytatható a kérdezés azzal, hogy vajon belátta-e, hogy Budapestre bevonulásának kevéssé az általa vezetett Nemzeti Hadsereg, mint inkább a megszálló román csapatok előrenyomulása volt az oka? Alappal hibáztathatta-e a fővárost, amiért „vörös rongyokba” öltözött, vagy e vörös máz nem csupán annak leplezéséül szolgált, hogy 1918-ra Budapest lakossága elfáradt és bármely eszme zászlója alá hajlandó lett volna bevonulni, amely nyugalmat, s valamiféle igazságtételt ígér az elmúlt évtizedekben szenvedő tömegeknek?

Az elmúlt két évben több olyan kötet is napvilágot látott, melyek a 20. század első felének magyar történelmét gyökeresen új aspektusból vizsgálják. E nóvum tulajdonképpen egy triviális fordulatban áll: forrásokon alapulva, objektív képalkotásra törekedni. Ezzel értelemszerűen együtt jár az elmúlt évtizedekben kialakult mítoszok lerombolása is, kezdve Horthy szerepének helyén kezelésével, vagy a kommunisták hátterének tisztázásával, végül, de nem utolsó sorban Magyarország tárgyalási pozíciójával a trianoni szerződés megalkotása során.

Hatos Pál és Ablonçy Balázs két vizsgált munkájában számos közös pont van, ugyanakkor bizonyos személyek bizonyos döntéseit másként látják. Egyikük sem először jelentkezik választott témájában új, rendszerező munkával, Hatos 2018-ban megjelent monográfiájáról bő egy éve tettem közzé gondolataim e folyóirat hasábjain. ${ }^{3}$

Ami közös a két korszakban, a két témában, az az, hogy az elmúlt évtizedekben valamennyi kurzus igyekezett a saját céljai érdekében hol nagyobb hangsúlyt biztosítani, hol eliminálni még a gondolatot is, hogy a (tudományos) diskurzus része lehessen. Trianon tragédiája bő száz éve velünk él, s jelenkori felfutásának katalizátoraként is értelmezhető, hogy a közelmúltban mintegy fél évszázadon keresztül nem lehetett része a közbeszédnek, így szükségszerűen kapcsolódott hozzá

\footnotetext{
${ }^{1}$ Hatos Pál: Rosszfiúk világforradalma. Az 1919-es Magyarországi Tanácsköztársaság története. Budapest 2021, 608 pp.

2 ABLONCZY Balázs: Az ismeretlen Trianon. Az összeomlás és a békeszerződés történetei, 1918-1921. Budapest 2020, 271 pp.

3 TIMÁR, Az emlékezet elsorvadásának számontartása 260-264.
} 
egyfajta misztikum. A proletárdiktatúra korszaka ezzel szemben még a megelőző állampárti rendszerben is sokáig tabunak számított annak ellenére, hogy 1945 után a kommunista vezetők szándéka szerint annak mintegy javított verzióját kívánták megvalósítani Magyarországon. Alappal merül fel a kérdés, vajon eltelt-e kellő idő a két tragédia óta ahhoz, hogy higgadt, tudományos alapokon nyugvó diskurzust folytathassunk e két periódusról. A két monográfiát vizsgálva kijelenthető, hogy eltelt, ugyanakkor ahhoz, hogy a szerzők által lerombolni kívánt mítoszok kikopjanak a közbeszédből, további lépések szükségesek.

Hatos könyvét komoly várakozás előzte meg, tekintettel az első köztársaságról írt munka kiemelkedő színvonala miatt. A várakozás nem volt alaptalan, a könyv stílusa továbbra is kellően egyedi, olvasmányos, amely a szakirodalmi munkáktól az elmúlt évekig kifejezetten idegen volt. A szerző számos, a korszakot meghatározó aspektust vizsgál. Első lépésként, már a bevezető fejezetben megdönt egy évtizedes mítoszt, miszerint a proletárdiktatúra a hazai zsidóság ügyeskedése volt, s a kommunizmus, valamint a zsidóság közé egyenlőségjel tehető. Helyesen állapítja meg, hogy a 133 napról írni tulajdonképpen lehetetlen, hiszen amilyen rövid és intenzív volt, annyira gyökértelen, s épp ellenkezőleg: árnyéka a mai napig tart. Ebben az árnyékban pedig meghúzódnak olyan szereplők, akik nemcsak a szélsőbal, hanem a szélsőjobb uralma idején is megőrizték helyzetüket, és egyaránt lelkesedtek valamennyi iránt - a kezdetekben. A Tanácsköztársaságnak is nevezett kísérlet egyaránt jelentette Kun Béla, Szamuely Tibor történetét, de jelentette Kodály Zoltánét, Illyés Gyuláét is, de aktív résztvevő volt az a Kármán Tódor is, aki később a hidegháború idején a NATO tisztviselőjeként fejezi be tudományos karrierjét, ${ }^{5}$ amiként Öveges Józsefböl is felszentelt pap lett annak ellenére, hogy 1919-ben ôt is megérintette a változás szele. ${ }^{7}$ De ehhez a történethez tartozik az a számháború, amit a két ellentétes oldal folytat évtizedek óta: melyik színt magán viselő terror követelt több áldozatot? E számháború olykor még napjainkban is fellángol, noha a Hatoshoz hasonló „csőszö̈k” időnként kikergetnek mindenkit az erdőből, hiszen „sem a vörös-, sem a rákeövetkező fehérterror megértésébez, nem elegendö csupán a mértékéröl tudni, és arról, hogy máshol, más orsqágokban többet öltek, vagy mások nemesebb eszmék nevében kinoztak.".

Hatos további fejezetet szentel a proletárdiktatúra kapcsán felmerülő „zsidókérdésnek”, ami jellemzően abból fakad, hogy a prominensek jelentős része érkezett zsidó felmenőktől - elhallgatva azt a tényt, hogy vallásukat természetesen nem gyakorolták, ${ }^{9}$ és azt a tényt is, hogy a vezetôk jelentős része katolikus volt, és vallásukat ők sem gyakorolták. A fejezet tételesen és kimerítően cáfolja a mítoszt, amely a későbbi rendszer antiszemita kommunikációját uralta. Ilyen címkét osztott bőkezűen Tormay Cécile is, amiként a proletárdiktatúrában funkciót vállaló Magyary Zoltán sem habozott a neki nem tetszők megbélyegzésével. ${ }^{10}$ De a szerző nemcsak a jobboldalnak rója fel a zsidósággal kapcsolatos féloldalas kommunikációt, hanem a baloldalt is emlékezteti a

\footnotetext{
4 Szóllöskislaki Kármán Tódor (született Kármán Tivadar Mibály, Budapest, 1881. május 11. - Aachen, 1963. május 6.) magyar származású gépészmérnök, fizikus, alkalmazott matematikus.

${ }^{5}$ HATOS, Rosszfiúk világforradalma 18.

6 Öveges József (Páka,1895. november 10. - Budapest, 1979. szeptember 4.) Kossuth-díjas piarista szerzetes, pap, tanár.

${ }^{7}$ HaTOS, Rosszfiúk világforradalma 21.

${ }^{8}$ HATOS, Rosszfiúk világforradalma 19.

9 Vö. Kun Béla kijelentése, miszerint az apja zsidó volt, ő viszont nem maradt zsidó, mert kommunista lett. HATOS, Rosszfiúk világforradalma 115.

${ }^{10}$ Hatos, Rosszfiúk világforradalma 99.
} 
„zsidókapitalista” bélyeg felragasztásának gyakorlatára is. ${ }^{11}$ Ugyanakkor e kérdés tárgyalásának terjedelme a könyvben épp úgy aránylik a többihez, mint amennyire a proletárdiktatúra kérdéseihez - egy fejezet, és a bevezető gondolatok némelyike.

A fejezetek egyébként jellemzően kronologikusak, a kezdőpontot - szerencsére - nem 1919. március 21-én jelölte ki a szerző, hanem korábban: a Károlyi-féle népköztársaság napjaiban. Kiemelendő, hogy időt és karaktert szentel a kommunizmus korai magyarországi történetének is, amiként a Forradalmi Kormányzótanácsnak nevezett testület összeállítását, tagjainak értékelését leíró korabeli álláspontoknak is. Tény, hogy e testület kevéssé volt a magas politikai-szakmai elit esszenciája. Az a tény, hogy a formális vezetô Garbai Sándor lett Károlyi helyett, ${ }^{12}$ ki is jelölte a közvetlenül megelőző rendszerhez való viszonyulást, s az ideológia, valamint a tapasztalat kapcsolatát - nem vitatva azt, hogy Károlyi is csak Kun Béláékhoz viszonyítva tünik alkalmasnak bárminemû politikai vezetésre. Hogy nem beszélünk Garbai-kormányról, az csak annak köszönhető, hogy e testületre csak annyiban volt hatása az elnöknek, mint amennyire Kádár János párttitkári árnyékéban Münnich Ferenc kormánya esetében beszélhetünk politikai önállóságról. Hatos ugyanakkor valamennyi népbiztosról, népbiztos-helyettesről közöl információ. E fejezet fontos jellemzője, hogy igyekszik követni azt a dinamizmust, amelyhez hasonlóval csak az ország területe változott a korszakban.

A kronologikus felépítést mindössze az töri meg, amikor az egyes társadalmi rétegek, osztályok bemutatására vállalkozik a szerző, ismertetve, hogy miként tudott túlélni a korábbi elit, miként igyekezett fennmaradását biztosítani a polgári elit, egyáltalán: maradhatott-e a polgárság Budapesten? Hatos - szokása szerint - nemcsak a fővárosra koncentrál, hanem a vidéket is bemutatja, s nemcsak a nagyvárosokat, vagy a határmenti térséget, hanem a kisebb, akár jelentéktelennek tűnőket is, ha az ott történtek a nagy egész megértését segítik.

Fontos és mindenképp új a ,forradalmi terror” megnyilvánulásait taglaló fejezet, amiként az a rész is, melyben a szerző a kommunizmus mint eszme bemutatására vállalkozik. Utóbbi esetben nem egyfajta ismertetőre kell gondolni, sokkal inkább arra, hogy miként viszonyult a kommunizmus ahhoz, ami addig volt, miként törekedett a Kun-féle puccsista társaság az ideológiai képzés kiterjesztésére, s a legfontosabb: hogyan viszonyultak a rosszfiúk a valláshoz és annak megnyilvánulásához: az egyházhoz. A „vörös” terrort taglaló fejezet ugyanakkor a kötet egyik legnyomasztóbb, leginkább megterhelő szakasza. Nemcsak azért, mert mintegy felütésként emlékezteti az olvasót Móra Ferenc idézett megnyilvánulására, ${ }^{13}$ hanem azért is, mert ezek a bűnök megtörténtek, és a terror eszkalálódása éles kontrasztban állt azzal, ahogy a kommunisták hatalomra kerültek. Már a kortársakban is felötlött a kérdés: ha a kommunizmus forradalom útján győzedelmeskedik, Magyarországon miként sikerült vér nélkül átvenni a hatalmat. Olyan kognitív disszonanciát okozott a párttagokban, hogy frusztrációjuk nem ismert határokat. A hatalomátvétel utáni napokban csüggedten konstatálták, hogy például a Vörös Ôrség is a korábbi állományt jelenti, csak új néven, amiként a mindennapok is az addigi mederben zajlanak. ${ }^{14}$ Ezt az ellentmondást mintegy feloldani igyekezvén került sor a Lenin-fiúk gründolására, Cserny József különítményének

\footnotetext{
11 HATOS, Rosszfiúk világforradalma 105

12 HATOS, Rosszfiúk világforradalma 78.

${ }^{13}$ HATOS, Rosszfiúk világforradalma 357.

${ }^{14}$ Hatos, Rosszfiúk világforradalma 358.
} 
megszervezésére. A történelmi emlékezet ugyanakkor hajlamos megfeledkezni arról, hogy nem csupán az 1919 őszén elítélt egykori cipészsegéd vezetett ilyen paramilitáris szervezetet, hanem mások is. ${ }^{15}$ Ellenben mit tehet a frissen hatalomra került ember, ha a ,forradalom" vér és ellenállás nélkül győzedelmeskedett? A válasz egyszerū és időtálló: kreálni kell belső ellenséget. A proletárdiktatúra első heteiben, hónapjaiban érdemi ellenállásról beszélni nem lehet, periférikusan volt egy-egy apró láng, de ezek hamar kimúltak, miként a bécsi Antibolsevista Comité is elmúlt az érdeklődés hiánya miatt. Az első, valamilyen formában komolyan vehető ellenállás a Nemzeti Hadsereg volt, mely Szegeden szerveződött, de idesorolható a Ludovika Akadémia növendékeinek ellenforradalmi kezdeményezése. Mégis, a belső ellenség listázása telefonkönyvből és az Országos Kaszinó tagnyilvántartásából állt össze, hiszen más - úgymond - nem volt. ${ }^{16}$ Itt érdemes talán megemlíteni, hogy Hortby - emlékiratai tanúsága szerint - a proletárdiktatúra idején rendszeresen ment a család kenderesi birtokáról Budapestre, hogy találkozzék elvbarátaival. ${ }^{17}$

További nóvuma a kötetnek, hogy tárgyalja az északi hadjáratot annak valamennyi sikerével és kudarcával együtt. Kiemeli, hogy miként változott a területvesztés elleni hadjárat egy, a világforradalmat segítő vállalkozássá, miként kapott a nemzeti küzdelem vörös színezetet. Persze, ehhez ütőképes hadsereg kellett volna, s a magyar haderő lelkiállapota Károlyi idejéből ismert. Nem véletlen, hogy a Vörös Hadseregbe való belépést csak fenyegetéssel tudták ösztönözni, miként a dezertálást is vadászezreddel kívánták megakadályozni. ${ }^{18}$ A tény, hogy a magyar csapatok Kassa felé vonultak, kevéssé volt annak betudható, hogy az északkeleti területek kiemelt magyar központja volt a város, hanem inkább annak, hogy itt nyílt esély arra, hogy a magyar és a szovjet-orosz haderő egyesülni tud ${ }^{19}$ - emlékeztetőül: a szovjet-orosz csapatok ekkor még bőven az intervenciós csapatokkal voltak elfoglalva. A kassai bevonulás után nagyon gyorsan kiderült, hogy nem a magyarok anyaországgal való egyesítése motiválta Kun Béláékat, hanem a kommunista internacionalizmus, hiszen a frissen fellobogózott várost hamar megtisztították a nemzeti színektől. ${ }^{20}$ Ugyanakkor érdemes kiemelni azt a megállapítást, amely szerint nem a területi integritást végtére is védelmező Károlyi, vagy Kun, hanem a trianoni országvesztést elfogadó, s a Szent Koronát többeknek felajánló, ${ }^{21}$ a proletárdiktatúra idején kifejezetten súlytalan ${ }^{22}$ Horthy maradt hatalmon és határozta meg az elkövetkező mintegy negyed évszázad magyar politikai életét - már amennyiben Horthy hatásának tekintjük az 1939 utáni eseményeket. Későbbi kormányzónk ugyan állítása szerint nyomban elfogadta, hogy Károlyi Gyula, majd később Betblen István kérésére csatlakozzon az akkor még aradi ellenforradalmi kormányhoz, ${ }^{23}$ Hatos jelzi, hogy ez azért korántsem történt ennyire magától értetődően. ${ }^{24}$ Nem hiába jelent problémát, hogy korszakonként eltérően emlékszünk egykori magatartásunkra. Ennek példája az is, hogy miként sikerült Ferenc József egykori

\footnotetext{
${ }^{15}$ HATOS, Rosszfiúk világforradalma 364.

${ }^{16}$ HATOS, Rosszfiúk világforradalma 367.

${ }^{17}$ HORTHY, Emlékirataim 123.

${ }^{18}$ HATOS, Rosszfiúk világforradalma 379.

${ }^{19}$ HATOS, Rosszfiúk világforradalma 384.

${ }^{20}$ HATOS, Rosszfiúk világforradalma 385.

${ }^{21}$ Hatos, Rosszfiúk világforradalma 392.

${ }^{22}$ HATOs, Rosszfiúk világforradalma 389.

${ }^{23}$ HORTHY, Emlékirataim 123.

${ }^{24}$ HATOS, Rosszfiúk világforradalma 389.
} 
szárnysegédjéből „A Hortby” megalkotása ${ }^{25}$ amit az érintett szerényen csak mint politikába sodródás ír le. ${ }^{26}$ Hogy a szegedi „ellenforradalmi” kormány mennyiben volt komolyan vehető, átgondolt és kormányzóképes erő, azt Hatos kifejezetten plasztikusan írja le a szegedi mulatozások és az antanttal folytatott kínosan egyoldalú kommunikáció bemutatásával. ${ }^{27}$

Ami viszont kiemeli Hatos munkáját, az a lezárás. A szerényen csak epilógusnak nevezett fejezet mintegy esszenciáját adja annak az esetlegességnek, hovatovább káosznak, ami a „dicsöséges” 133 nap és Horthy kormányzóvá választása között végbement az országban. Hajlamosak vagyunk elfelejteni, hogy ekkor Magyarországgal még mindig nem kötöttek békét, s bár az 1918. évi fegyverletétel óta kellő idő telt el, körülöttünk az új országok létrejöttek, berendezkedtek, idehaza még ekkor sem volt olyan főhatalom, amelyet egyaránt elismertek volna belföldön és Párizs környékén is. A szakszervezetinek is nevezett kormány első intézkedései tulajdonképpen a proletárdiktatúra ámokfutása eredményeinek felszámolása voltak a vörös epizód utáni napokban. Politikailag motivált büntetőeljárások tucatjait kellett megszüntetni, fel kellett számolni a Forradalmi Törvényszékeket, helyre kellett állítani az igazságszolgáltatást, vissza kellett adni a magántulajdont - tulajdonképpen ellenkező előjellel mindazt, amit Kun Béláék „forradalmi” hevületükben igyekeztek napok alatt véghez vinni. Tevékenységükben mindenképp azonos volt a siker és az elfogadottság mértéke. Az már csak amolyan magyar sajátosság, hogy egy héten belül puccs vitte el a Peidl-kormányt, mégpedig az 1919. augusztus 6-i minisztertanácsi ülés közepén, amelynek során Garbai intézkedett, hogy ha már puccs történt, legalább ne éhgyomorral kelljen a két oldalnak elrendezni a hatalomváltást. ${ }^{28}$ Meg kell jegyezni, hogy a hatalomváltás a legtöbb helyen kevéssé fraternizáló légkörben zajlott, a Dunántúlon nem egy esetben a népharag sodorta el az egykori direktóriumi tagokat, de természetesen az ilyenkor szokásos pogromok (és a hadseregben a később numerus claususként ismert korlátozás alkalmazása ${ }^{29}$ ) is napirendre kerültek. ${ }^{30} \mathrm{E}$ két eseménysor egymáshoz való viszonya álláspontom szerint hozzávetőleg hú képet ad az 1918 utáni magyar állapotokról, valamint az uralkodó elit és a társadalom alsóbb rétegei közti összhang mértékéről. Természetesen nemcsak a magántulajdon visszaadása, vagy a vörös kísérlet eredményeinek visszabontása volt sürgető feladat, hanem azok számonkérése is, akik részt vettek ebben a lázálomban. E számonkérésnek lett része aztán a népbiztosper, melynek során számos személyt ítéltek halálra, s egy részüket később fogolycsere keretében a szovjetek kezére adtak, cserébe magyar hadifoglyok térhettek haza. Utóbbiak között volt az a Rajniss Ferenc, aki ekkor még elítélően nyilatkozott a zsidóüldözésről és a fehérterrorról, noha közvetlen tapasztalata volt a hadifogolytáborban a forradalomról és az ellenforradalomról is. ${ }^{31}$

A Tanácsköztársaságra évtizedeken keresztül akként hivatkozott a hivatalos, központilag vezérelt pártállami kommunikáció, mint valamifajta forradalmi események nyomán létrejövő rendszerre, ugyanakkor szükséges látni, hogy a 20. század magyar történelme nem más, mint egymásra tolódó rendszerváltások sorozata - átlagosan minden évtizedre jut egy rendszerváltás. Az

\footnotetext{
${ }^{25}$ HATOS, Rosszfiúk világforradalma 391.

${ }^{26}$ HORTHY, Emlékirataim 133.

${ }^{27}$ HATOS, Rosszfiúk világforradalma 395.

${ }^{28}$ HATOS, Rosszfiúk világforradalma 465.

${ }^{29}$ Hatos, Rosszfiúk világforradalma 468.

${ }^{30}$ Hatos, Rosszfiúk világforradalma 466.

31 SIPOS, Szálasi minisztere voltam 10.
} 
is kijelenthető, hogy a tanácsköztársaság, mint addig és azóta sem alkalmazott államforma nem tekinthető se többnek, se kevesebbnek, mint egy megváltozott körülményekre adott válaszkísérletnek, amelyből több, vagy kevesebb áldozatot eredményezve, de találunk más példát is a hazai történelemben.

A Kun Béla vezette kommunista párt által végrehajtott puccs nem élvezte a kezdetektôl a tömegek támogatását, mi több, nemcsak a vidék, de a főváros lakosságát is meglepte, ${ }^{32}$ bár a későbbi, ugyanakkor a pártállami időben, 1969-ben megjelent szakirodalom ezt igyekszik úgy beállítani, mintha a levegöben lógott volna a forradalom, ${ }^{33}$ Szelefü Gyula egy helyen alig tizenötezer támogatóról ír. ${ }^{34}$

Nem meglepő módon az új, szélsőséges baloldali kurzus igyekezett az élet valamennyi területén radikalizmussal, a hagyományokkal való szakítással ellensúlyozni támogatottságának gyakorlatilag teljes hiányát. ${ }^{35} \mathrm{~A}$ radikalizmust magyarázta ugyanakkor az is, hogy a háború utáni közbiztonság gyakorlatilag mélyponton volt, sokszor a csendőrség sem volt képes rendet teremteni, gyakoriak voltak a szomszédos falvak közti kvázi rablóháborúk. ${ }^{36}$ Ugyanakkor Kun Béla és társai dolgát nehezítette, hogy a példaként elöttük álló szovjet-orosz minta is kiforratlan, mi több, meglehetősen ingatag volt - ne feledjük, hogy a szentpétervári hatalomátvétel óta alig másfél év telt el, miközben a bolsevik erők az intervenciós csapatokkal álltak harcban.

Feltehetően nem segítette a dualizmus utáni magyar társadalom általi elfogadást az a tény sem, hogy a „Mindenkihere!” című kiáltvány tudatta a polgárokkal, hogy a törvényhozó, a végrehajtó és az igazságszolgáltató hatalom gyakorlása a „munkás-, paraszt- és katonatanácsok diktatúrája” útján történik. Hatos pedig ezt a disszonanciát, a teljes proletár rémuralmat plasztikusan, forrásokkal kellően alátámasztva írja le, amivel a hazai historiográfia régi adósságát törlesztette. Kimaradt ugyanakkor az igazságszolgáltatás szervezetrendszerének és hivatásrendjeinek bemutatása, ${ }^{37}$ mely kapcsán jelen sorok szerzője egyszerre fejezi ki köszönetét és hiányérzetét is, hiszen meggyőződése, hogy az állam diszfunkcionalitása leggyakrabban és legkönnyebben az igazságügyi kormányzat működésén keresztül mérhetô le mind a mai napig.

A fent tárgyalt alig néhány hónap annak a vesszőfutásnak volt része, amely az 1918 és 1920 közötti időszakot jellemezte belföldön és külföldön egyaránt. Ez az időszak a magyar történelem egyik legváltozékonyabb időszaka. Nemcsak az ország területe változott szinte napi szinten, de az aktuális területen hatalmat gyakorló személyek köre és legitimációja is. A vizsgált korszak kezdetétől, 1918. október 30. napjától Hortby kormányzóvá választásáig (1920. március 1.) de iure négy, de facto hat kormány volt hatalmon, legrövidebb ideig a Hadik-kormány, mintegy 17 órányit. Az őszirózsás forradalom előestéjén kikiáltott nemzetállamok okozta területvesztésre az állam valamennyi szervének és a hétköznapoknak is reagálnia kellett, előbbit pedig nehezítette a tény, hogy a köztársaság kikiáltása nyomán megszűnt az addigi hatalomgyakorlás eredője: a királyi hatalom.

\footnotetext{
32 RoMSICS, Magyarország története 124.

33 HAjDU, A Magyarországi Tanácsköztársaság 23.

34 SZEKFÜ, Rövid magyar történet 504.

35 Romsics, Magyarország története 124.

${ }^{36}$ HATOS, Az elátkozott köztársaság 176.

${ }^{37}$ TIMÁR, A bírósági szerveztrendszer változásai 175-186.
} 
Ablonçy munkája látszólag két célt szolgál. Egyfelől a centenáriumra készülvén kívánta új fényben bemutatni a trianoni béke történetét, másfelől ismertetni kívánta azt, hogy a hétköznapokban miként csapódott le a területvesztés. Előbbi kapcsán kiemelendő az a nemzetközi kontextus, amiben tárgyalni érdemes a kérdést, hiszen Trianon megítélése sok szempontból a magyar elitre jellemző köldöknézegetésben gyökerezett, míg a társadalom alsóbb rétegeiről hajlamosak vagyunk megfeledkezni - pedig végtére is a történelem a társadalom mindennapjaira hat a leginkább.

Ebben rejlik Ablonçy monográfiájának egyik legnagyobb erénye. A környező országok nemzetállami törekvéseit előítélet nélkül, már-már a neutralitásba hajló történészi hidegvérrel tárgyalja, egyúttal bemutatja, hogy az egyes politikai aktorokra milyen sors várt a nemzetállam megszilárdulása után. Hangsúlyos része a kötetnek, hogy miként költöztek az egyetemek az anyaországba, melyek centenáriuma idén van. Trianon ugyanakkor nemcsak az egyetemköltözéseket és a migrációt jelentette, hanem a radikális gyakorisággal jelentkező impériumváltásokat is, egyszersmind olyan kérészállamok létrejöttét (vagy papíron maradását), melyeknek a létezésérôl a közelmúltig a szélesebb közvélemény nem is tudott. Ez utóbbi téma ugyanakkor veszélyesen könnyen sodorhatja a történelmi bulvár felé a szerzőt, mégsem teszi, hiszen ezen kísérletekben kevéssé az a szenzáció, hogy léteztek, hanem az a gondolatiság, amelynek nyomán egyáltalán felmerïlt a létezésük.

A tény, hogy több, mint egy tucat ilyen szerveződés létrejött Közép-Európa egykori vezető hatalmának területén, mutatja, hogy mekkora káoszt jelentett az Osztrák-Magyar Monarchia felbomlása. Az ilyen államkezdemények igyekeztek magukat az államiság vélt, vagy valós jelképeivel felruházni, saját zászlót, címert alkottak, bélyeget bocsátottak ki, nem ritkán hadsereget is szerveztek, sőt, extrém esetben még valamiféle nemzetközi elismerésre is szert tehettek - már amennyiben nemzetközi elismerés, hogy a frissen és véresen létrejött Szovjet-Oroszország elismerte a fiumei államkezdeményt. ${ }^{38}$ Nem szabad ugyanakkor ezt valamiféle közép-európai sajátosságnak tekinteni, hiszen 1918 után számos helyen kívánták függetleníteni magukat egyes csoportok. $^{39}$

Abloncsy szinte triviálisnak ható választ ad arra a kérdésre, hogy miért tűntek el ugyanolyan gyorsan ezek az I, amilyen gyorsan létrejöttek: a kidolgozatlanság és az identitás hiánya. Vitatható ugyanakkor az az állítás, hogy a Tanácsköztársaság és a Károlyi-féle népköztársaság közül utóbbi nem kérészállam, előbbi pedig az, ${ }^{40}$ bár a felsorakoztatott érvrendszert el lehet fogadni. Tény ugyanakkor, hogy Kun Béla és társai kísérlete végső soron a magyar állam valamiféle reprezentánsa akart lenni, még akkor is, ha épp az ehhez szükséges kontinuitást tagadta meg, igaz, elvi-politikai alapon. Ellenben vitathatatlan, hogy bármennyire is radikálisak voltak a rossz̧iúk, a múltat végképp nem sikerült eltörölni, ́́gy felfedezhetô a folytatólagosság.

Kiemelendő körülmény, hogy annyi kérészállam jött létre, hogy azok már osztályozhatók is aszerint például, hogy milyen véget értek, vagy megalkotásuk belülről vagy kívülről történt-e. ${ }^{41}$

\footnotetext{
38 ABLONCZY, Az ismeretlen Trianon 145.

39 ABLONCZY, Az ismeretlen Trianon 152.

40 ABLONCZY, Az ismeretlen Trianon 148.

${ }^{41}$ ABLONCZY, Az ismeretlen Trianon 149.
} 
Érdekes és érdemes vizsgálni azt is, hogy milyen vezérlő ideológia mentén szerveződtek ezek a kezdeményezések, egyáltalán: volt-e valamiféle ideológia mögöttük? ${ }^{42}$

S ha már Ablonczy elmélkedik a Tanácsköztársaság ilyetén megítélésén, érdemes kitérni egy olyan aspektusra, melyet mindkét szerző érint, de eltérő szemszögből. Évtizedek óta tartja magát a legenda, hogy a trianoni béke súlyossága annak köszönhető, hogy Magyarországon a hatalmat a kommunisták szerezték meg 1919-ben. Tény, hogy Kun Béla amolyan magyaros mentalitással közelített a békedelegációhoz, ${ }^{43}$ de az is tény, hogy bár a proletárdiktatúra kiépítése Párizsban riadalmat keltett, de többen felvetették, hogy ez a békekonferenciának is köszönhető, hiszen a demarkációs vonalakat övező kommunikáció elégtelen volta mintegy belekergette a magyarokat a vörös uralomba. ${ }^{44}$ Trianon és a proletárdiktatúra viszonyának megítéléséhez álláspontom szerint elengedhetetlen, hogy a körülményeket figyelembe vegyük.

A kérészállamok átfogó ismertetésén túlmenően Ablonçyy munkájának másik vívmánya az impériumváltások lélektanának bemutatása, melynél érdemes időzni. Olyan mértékủ dilemmáról szól a kötet egy teljes fejezete, melynek súlyát jelen korunkban elképzelni sem tudjuk. S itt nem általános ismertetésre kerül sor, hanem nagyon is konkrét példákat hoz a szerző, többek között Szatmárnémeti hivatalnokainak eskütételét, melyre azt követően került sor, hogy az újonnan kinevezett román prefektus mindenkit megnyugtatott a magyarkérdés rendezettségéről, s végül az eskütétel után valamennyit elbocsátották. ${ }^{45}$ Természetesen ez a folyamat sem egységesen zajlott le, hiszen a románosítás intenzitását döntően befolyásolta az a tény, hogy az adott terület milyen messze volt az anyaországtól, illetve milyen tétje volt a nemzetépítésnek, de olykor olyan banalitások is, mint pl. területi vita két új nemzetállam között, mint történt az a Bánságban. ${ }^{46} \mathrm{~S}$ az eskütétel nemcsak a közigazgatás állományára várt, hanem az oktatókra is, ráadásul kiterjedt a később Magyarországon maradt, de az 1918 után megszállt területekre is, mint az látható Baja példáján, amely eskük nyomán később a magyar állam több jogszabállyal igyekezett mintegy menteni a menthetôt és az ilyen esküket mint kikényszerített aktusokat kezelni. ${ }^{47} \mathrm{~A}$ dilemmát egészen mikroszinten mutatja meg Poprád és Salgótarján polgármestere, Förster Kálmán sorsa, akinek a menni vagy maradni dilemmájával is szembe kellett néznie, hiszen vagy az esküt teszi le az új államra, vagy a szülőföldjét kellett elhagyja. ${ }^{48}$

S ha már a hatalomváltás felmerült, érdemes elidőzni azok sorsa fölött, akik az anyaországba költözés mellett döntöttek. Az utókor hajlamos úgy tekinteni a korabeli magyar államra, mint amely menedéket nyújtott az otthonukból elüldözöttek százezreinek, a valóság ezzel szemben az, hogy az 1920 utáni magyar állam menekültpolitikája legalábbis ellentmondásosnak értékelhető. Minthogy a megszálló hatalmak igyekeztek elsődlegesen a szimbolikus terek és intézmények lerombolásával erôt demonstrálni, nem véletlen, hogy a szobordöntéseket követte a magyar állami szimbólum szintjére emelt államvasúttal és annak dolgozóival szembeni eljárás, melynek köszönhetően a menekültek

\footnotetext{
42 ABLONCZY, Az ismeretlen Trianon 151. sk.

${ }^{43}$ RomsiCs, A trianoni békeszerződés 110.

${ }^{44}$ RomsiCs, A trianoni békeszerződés 108.

45 ABLONCZY, Az ismeretlen Trianon 168.

46 ABLONCZY, Az ismeretlen Trianon 170.

47 ABLONCZY, Az ismeretlen Trianon 171.

48 ABLONCZY, Az ismeretlen Trianon 179.
} 
első hullámát a közlekedés és a távközlés dolgozói jelentették. ${ }^{49}$ Természetesen a beáramlás sem 1920-ban kezdődött, ám hivatali szinten 1920 előtt nem beszélhetünk ennek kezeléséről, s 1924ben formálisan is megszűnt az Országos Menekültügyi Hivatal. Később maga Betblen István emelt szót az évi 290.000 beérkező menekült kapcsán, ${ }^{50}$ hovatovább Teleki Pál rendeletben kategorizálta az országba érkezőket. ${ }^{51}$ Abloncæyy ugyanakkor a historiográfia nóvumaként alkalmazott naplókutatást is alkalmazza, hiszen forrásai közé került egy besztercebányai tizenéves naplója is, amely nemcsak a menekülés, hanem a benyomuló Vörös Hadsereg megítélésérôl is szól. ${ }^{52}$

Kiegészíti-e egymást a két kötet - merülhet fel a kérdés az olvasóban. A válasz egy mérsékelten határozott igen. Ennek okai között szerepel az, hogy más megközelítést alkalmaznak, hiszen míg Hatos egy viszonylag jól körülhatárolható korszakot igyekszik bemutatni annak majdnem minden aspektusából, addig Ablonçy egy történelmi instrumentumot és annak elő-, valamint utóéletét. Utóbbinak természetesen immanens része előbbi, így, ha nem is egészítik ki egymást, utóbbi megértéséhez előbbi ismerete erôsen ajánlott. Annál inkább ajánlott, mert a felhasznált primer források mennyisége és minősége is impozáns, ugyanakkor a kiadó egyik esetben sem könnyítette meg a jegyzetek megismerését, hiszen ismét a kötet végén, egyben közli valamennyit, így nehezíti a szakirodalomként való felhasználhatóságot.

Több mint száz évvel a vizsgált események után a magyar historiográfia kezd feléledni abból a politikai álomból, melybe közvetlenül 1920 után süllyedt, s amelyből látszólag a rendszerváltás után sikerült magához térnie. Az elmúlt néhány zűrzavaros évtized után olybá tűnik, hogy felnőtt az a történészi generáció, amely képes és hajlandó politikai kurzusokon átívelő tárgyilagossággal közelíteni a XX. századi magyar történelem neuralgikus pontjai közül kettőhöz. Ez egyúttal kijelöli azt az időbeli távolságot, amelyet ki kell várnunk ahhoz, hogy 1956 feldolgozása is megtörténjen. Trianon szakirodalmi (és olykor nem szakirodalmi) feldolgozottsága kiemelkedő, a centenáriumi emlékév során számos konferencia, monográfia, tanulmánykötet volt, így Abloncsyy (és az általa vezetett kutatócsoport) számára a feladat kettős volt: újat adni és kitűnni a tömegből - mindkét feladatot sikerrel abszolválták. A tanácsköztársasági emlékezet ugyanakkor a magyar történelem kevéssé szalonképes rokona, akit igyekszik mindenki elfelejteni és ha feltűnik, illedelmes csöndben megvárni, míg távozik. Hatosnak mégis sikerült átfogó és kellően árnyalt képet adni arról a 133 napról, amely csak évtizedekkel később, bőven az állampárti rendszerben került középpontba.

S ha már a centenárium felmerült, érdemes megemlékezni arról, hogy míg Ablonçzy kutatása a már többször említett emlékév ívébe illeszthető, addig Hatos két legutóbbi munkája kapcsán hiába a kerek évforduló - elmaradt a megemlékezés intézményes formája. Ez a Tanácsköztársaság kapcsán megérthető, hiszen a terror nem érdemel emlékévet, ugyanakkor a Károlyi-féle népköztársaság kapcsán ordító a hiányosság, s nehéz nem arra gondolni, hogy állami szinten még mindig tartja magát az a mítosz, amely a bethleni konszolidáció nyomán vált széles körben elterjedté: a két „köz̨társaság” tulajdonképpen egy és egyként felelősek a nemzet 20. századi tragédiái közül az elsőért. A Rosszfiúk világforradalma tehát nemcsak az Ismeretlen Trianon mellett értékelendő, hanem az Elátkozott köztársaság mellett is, hiszen a két köztársaság alapvetô és nagyon is jellegadó

\footnotetext{
49 ABLONCZY, Az ismeretlen Trianon 186.

50 ABLONCZY, Az ismeretlen Trianon 189.

51 8352/1920. M.E. sz. rendelet, ld. ABLONCZY, Az ismeretlen Trianon 190.

52 ABLONCZY, Az ismeretlen Trianon 195.
} 
különbségeit mutatja meg, amelyek nyomán még égetőbb a kérdés: hová lett a központi megemlékezés az első magyar köztársaságról.

Üdvös és folytatandó a két szerző által megkezdett irány, amiként a Jaffa Kiadót is dicséret illeti, amiért e kötetek megjelenését lehetôvé teszi. A közelmúlt olykor viharos átkeretezése mellett mindenképp szükségesek azok a stabil pontok, amelyeket e munkák jelentenek, hiszen nemcsak a korszakot, a szereplőket és azok motivációját mutatják be, hanem egyszersmind kijelölik azt a módszertani minimumot is, amely ahhoz szükségeltetik, hogy vitatkozni lehessen állitásaikkal. Ez utóbbi kapcsán pedig kiemelendő, hogy főleg Hatos monográfiája fondjegyzékként sem utolsó, hiszen a bőséges szakirodalom mellett a levéltári források is segíthetik az eljövendő kutatógenerációk munkáját.

S végül a szerzők stílusa - tágabban. A honi történelemtudomány (s általában a tudomány) évtizedek óta küzd azzal, hogy az emberekhez közel vigye annak eredményeit. Ennek következményeit látni lehetett akár a koronavírus-járvánnyal összefüggő „szkepticizmus”, akár az ennek örvén megerősödő hangok elterjedése nyomán is. Mindkét szerző érdeme, hogy nemcsak konferenciákon, szakcikkekben, hanem a modern média útján is igyekeznek eljuttatni mondanivalójukat a széles közönséghez. Teszik mindezt olyan stílusban, amely közérthetősége és olvasmányossága mellett megmarad szakmainak is, kijelölve annak lehetőségét, hogy a tudomány nem kell szüleségszerüen száraz legyen, s a közérthetöség nem kell a szakmaiság rovására menjen. Mindkét szerző tökéletesen reagált az újabban egyre gyakrabban felmerülő megváltozott olvasói szokások jelentette kihívásokra, így munkásságuk a magyar történetírás új korszakát is jelentheti. A kérdést inkább úgy érdemes feltenni, hogy ez az irány zárványként jelentkezik-e, s idővel visszatérünk az ötven évvel ezelőtt meghaladottakhoz, vagy sikerül ezt folytatni, amely utóbbi várhatóan magával hoz egy sajátos impériumváltást is, de a történelemben tapasztalt radikaližmus nélkül.

\section{Felhasznált irodalom és források}

ABLONCZy Balázs: Az ismeretlen Trianon. Az összeomlás és a békeszerződés történetei, 1918-1921. Budapest 2020 HAjDu Tibor: A Magyarországi Tanácsköztársaság. Budapest 1969

HATOS Pál: Az elátkozott köztársaság. Budapest 2018

HATos Pál: Rosszfiúk világforradalma. Az 1919-es Magyarországi Tanácsköztársaság története. Budapest 2021

HORTHY Miklós: Emlékirataim. Budapest 1992

RoMSICS Ignác: A trianoni békeszerződés. Budapest 2020

RoMsICs Ignác: Magyarország története a XX. században. Budapest 2005

SIPOS Péter (szerk.): Szálasi minisztere voltam - Rajniss Ferenc naplója. Budapest 2021

SZEKFƯ Gyula: Rövid magyar történet 1606-1939. Budapest 2002

TiMÁR Balázs: A bírósági szerveztrendszer változásai 1918 és 1920 között a káosztól a konszolidációig. Magyar Jog 2021/3. sz. 175-186.

TiMÁR Balázs: Az emlékezet elsorvadásának számontartása Gondolatok Hatos Pál: Az elátkozott köztársaság címú könyvéről. Díké 2020/1. sz. 260-264. 